\title{
Art and Spirituality in the Covid-19 Epoch: An Exploratory Reading of Ben Okri's Poetry
}

\author{
Nelson S. Ratau \\ Department of English \\ University of Zululand \\ KwaDlangezwa 3886 \\ South Africa \\ E-mail:rataun@unizulu.ac.za \\ Doi: https://doi.org/10.46222/pharosjot.102.214
}

\begin{abstract}
Covid-19 has infected approximately 160 million people globally since its first occurrence in China in 2019. Consequently, the whole world has been negatively impacted, with numerous people losing their lives, jobs and loved ones, including breadwinners in families. With the prevalence of the pandemic also came various views on the challenges that came with it. Literature cannot be left out of the modes that are providing an understanding of the negative impact of Covid-19 on the world. Therefore, this paper explores the poetry of the Nigerian poet, novelist and essayist, Ben Okri, in light of his thematisation of spirituality. By spirituality, it is meant the 'recognition of a feeling or sense or belief that there is something greater than myself', the times and situation(s) in which one exists'. In this paper, Okri's poetry is considered as an essential index into how 'the spiritual' is conceived and articulated, even in times of pandemics. The paper adopts the Hermeneutical Approach as a theoretical lens through which Okri's poetry may be best viewed and understood. The Hermeneutical Approach essentially entails the analysis of texts in order to develop insight or thoughtful wisdom. Furthermore, the paper proffers that Okri's poetry is invested with a spiritual temper that makes it relevant as it encourages and makes and keeps 'awake' a spiritual sensibility in the people during the Covid-19 pandemic. The analysis is undergirded by a predetermined set of themes, namely; race, identity, healing, spirituality, thought and consciousness that Okri poeticises about and subsequently interrogates in his poetry. In the process, Okri's poetry also encourages spiritual renaissance and the awakening of consciousness, by tempering in a reader the inalienable fact that to change or shape reality, people ought to do it themselves. Okri's poetry challenges people to define themselves and defy all false definitions of themselves made by others. Ultimately, the paper explicates that Okri's poetry is charged with pointed rebuke of people's apparent apathy towards issues such as freedom, equality and transformation (all of which belong to the great stream of 'the spiritual'), of which he submits that people ought to take charge of how these three important entities come about and exist in society.
\end{abstract}

Keywords: Art; Covid-19; Healing; Hermeneutics; Hope; Poetry; Spirituality

\section{Introduction}

Ben Okri is a Nigerian poet and novelist who has reached international acclaim and is often described and considered Africa's leading writer in the post-modern and post-colonial traditions (see Ben Okri, Editors, The Guardian, 22 July 2008). Okri's writing began in 1976 while waiting to be granted a place in a science course at a Nigeria university; the application was unsuccessful; Okri then left Nigeria for London in 1978, where he worked as a staff writer for the magazine Afroscope. His debut novel entitled Flowers and Shadows (1980), was written while he was living in Nigeria. The novel revolves around a young man's disillusionment with corruption in a post-colonial Nigerian society (Tunca, 2011). In 1981, Okri published his second novel, The Landscape Within (1981), which he later reworked and was published with the title Dangerous Love, which focuses on the daily life and artistic aspirations of a young 
painter named Omovo. His most famous work, The Famished Road, was awarded the 1991 Booker Prize, along with Songs of Enchantment and Infinite Riches (see The Booker Prizes Backlist | The Booker Prizes), which is a trilogy that follows the life of Azaro, an abiku or a spirit-child narrator, through the social and political turmoil of an African nation reminiscent of Okri's remembrance of war-torn Nigeria. "Azaro, the first person narrator of the story, lays heavy emphasis on a millennial vision of world history and on prophesies of an imminent second coming" (Obumselu, 2011:27). In his writing, Okri mixes a number of literary traditions such as New Ageism, magical realism, existentialism and Yoruba folklore. Some scholars have described Okri's work as belonging to the category of magical realism, a categorisation he completely rejects by saying that critics who read his work through the magical realism lens confuse his use of the spirit-child narrator "as just a literary device", while in fact he is depicting "someone else's reality" (Okri, 2010). Scholars such as Obumselu give a balanced description of Okri's use of the spirit-child narrator by saying that Okri "does not have to believe that spirit children exist in the real world. In all probability, he does believe that spirits and spirit children are out there" (Obumselu, 2011:27). He goes further to state that:

\begin{abstract}
"Objectively, abiku may just be a notion in which West African societies have taken refuge against the scourge of mosquito infestation and the endemicity of sickle cell anemia in the sub-region. But a writer who holds this view could still use an abiku in his work as a fictional convenience to achieve a particular imaginative effect (Obumselu, 2011:27).
\end{abstract}

Whenever havoc is wreaked upon the world by all manner of evil, misfortune and challenges such as Covid-19, which many have since come to dub "an invisible enemy", people are often in need of practical solutions such as food, housing for their protection, medicine for their ailments, roads and infrastructure for their commerce. When war or starvation rages, people never run to a novel, poem or a painting, for as Okri (2015) once said, "a poem never stopped a bullet". For this reason, there have been questions about art's function and practical use in society. Finding the answer to this question has proven, and still proves to be fruitless as art would not give an answer on what its practical function in the world is. In a preface to his most famous novel, The Picture of Dorian Grey, Oscar Wilde states that, "partially and paradoxically" (cf. Okri, 2015), "all art is quite useless" (Wilde, 1891:4). Okri (2015) shares in the view that art (this includes poetry, dance, music, painting, etc.) "cannot save the world", at least in the practical sense as would Alexander the Great's sword that untied/cut through the famous Gordian knot, or as water that quenches a raging thirst.

Art has been asked to show its practical function in society. There are many people, critics and artists who dismissed and still dismiss the rather skewed demand of art's practical use, for art, as Okri (2015) would have it, cannot be compared and expected to have a practical function as that of a bomb, so to speak. He further observes that the less a work of art can be used, the more artistic it is (Okri, 2015). Okri (2015) views art as that which operates on our consciousness (2015). Art (literature/poetry) should be viewed through the same lens as the holy books (which are often alternatively referred to as 'spiritual books), the Bible, the Talmud, the Vedas and the Quran, and others, because like the holy books, art (poetry) is metaphorical, representative or symbolic; art touches on wisdom, like the Bible's proverbs and produces deeper meanings and thoughts as would the psalms of David. Poets and writers such as the Lebanese-American poet, Kahlil Gibran, and the Persian poet, Mawlana Jalal al-Din Muhammad Rumi, produced literary works that share stylistic aspects and the use of language as that of the holy books (Zabán, 2016; Horea \& Horea, 2014; Jourbert, 2007; Dirven \& Bernard, 1991). The holy books, which are also generally referred to as spiritual books, are all about encouraging the spiritual wakefulness of converts or believers, by affirming in and to them that there is more to life, the world and themselves. Okri is a 'question asker', a concept he coined/adopted to refer to and describe the central characters of his most recent novel, The Freedom Artist. More than that, Okri is a poet-seer, a dreamer and conjurer and qualifies as what Percy Shelley called 'the unacknowledged legislators' (poets who ask deep and 
critical questions of their society). There are those critics and scholars such as Christopher Warnes (2009) who regard him as a faith-based writer. Okri can also be put in the class of the spiritual/teacher-seer (in the poetic sense, of vision and poetic thought)/philosophical poets such as Mawlana Jalal al-Din Muhammad Rumi and Kahli Gibran, whose poetry deal with issues of the world and human life on a spiritual poetic plane. These are poets who, like Okri, cherish(ed) the idea of the "aesthetic" or the poetic as "functional" in a deeper and "higher sense" (Okri, 2013).

It is this paper's main objective to explore Okri's poetry as serving a spiritual function, particularly in the era of Covid-19. The paper argues that art (poetry in this case), has a spiritual function in human life. Virgil as cited in Pangani (2016:160) states that "art is capable of revealing to us what no science can ever reveal to a human mind." The paper will explore salient thematic issues in Okri's poetry, selected from collections of his poems i.e. A Fire in My Head: Poems for the Dawn (2021), An African Elegy (2015), Wild (2012) and Mental Flight: An Epic Poem (1999), and subsequently interpret them in relation to the Covid-19 times and spirituality.

\section{On Spirituality and Art}

The English word 'spirit' was derived from the Latin word 'spiritus', meaning, 'soul, courage, vigor and breath' (Lepherd, 2015:567). Harper cited in Leperd (2015:567) states that the word spirit generally alludes to a person's psyche (soul). Lepherd (2014:568-569) posits that:

There are various models for what is included in spirituality, and they all generally include values and beliefs that can lead to a greater meaning in a person's life. Values have many aspects and can include love, hope, trust and wisdom, as well as honesty and imagination, and can also increase the sense of well-being.

The psychiatrist, Dr. Maya Spencer, describes spirituality as that which involves the recognition of a feeling or sense or belief that there is something greater than myself, something more to being human than sensory experience, and that the greater whole of which we are part is cosmic or divine in nature (Spencer, 2012). Key in Spencer's description of spirituality is the idea of 'belief that there is something greater than myself', which invites the idea of hope. Spirituality can therefore be described as a person's soul, an inner landscape where hope is wrought and kept.

In an interview with Charles Henry Rowell when Okri was asked these questions, "Will you talk about what you make as art? What is it, how it moves in the world, how you want it to exist in the world, and how you want us to respond to it or experience it?" (Rowell, 2014:214), he answered: "I see art as a bridge between the secular and the spiritual aspects of humanity. In art I'm including everything from song, dance, architecture, painting, music, literature, conversation of a certain kind, even certain silences. Society is held together by laws, but it is animated by art" (Rowell, 2014:214).

Art is always on the mode of evolution, it changes with the times, and therefore, there can be no definite definition of what art is. Art can only be described with regard to its aesthetic nature. It is this aesthetic nature of art that gives it the power or effect to appeal to the human soul and spirit. To define art or say what really it is, is perhaps to limit it. But art cannot be limited to ourselves, our groups, our tribes, our race, our ideology, our religions, our politics, our limitations (Okri, 2015). In a way, art is ever modifying itself beyond definitions, cultures and ideologies. It is rebellious, and its first rebellion is with function (Okri, 2015). The best way is to describe art as a medium of imitation, representation, transmission and intuitive expression (Davis, 2018; Plato, 1995; Tolstoy, 1995; Croce, 1920; Bell, 1914). Art imitates life, human behaviour and society, and the behaviour of the human soul, as well as its inclination to dream. Art is a form of representation of life through the utilisation of symbolism and language. Art is also used to transmit ideas and feelings of a person or people (Tolstoy, 1995). It is to a person's psyche (soul) that art speaks. Art operates on the human mind. It appeals to the 
spiritual in a human being. As Okri (2013) observes, "the mind craves beauty, that the soul is nourished by beauty" - art is beauty.

Mich (2017) opines:

\begin{abstract}
The essence of poetry has always been found in nature with spirituality as a guiding partner through the unknown. Poems have been written not only as an expression of the unknown but also as a memory to that which has been experienced. They have the power to convey the unfathomable and the grace to glide the reader into the experience.
\end{abstract}

Art is in fact water, food, balm or medicine for the human spirit, soul and mind. In an article entitled The Role of Art in Society with Particular Reference to the Problem of Violence, Pagani (2016:160) submits this thesis: "art can play an extremely beneficial role in society as it can strongly foster humans' efforts to attain a deeper and broader comprehension of reality".

Art has its source in the unconscious; and "its greatest effect is on our unconscious" (Okri, 2015). This speaks to the idea that poetry is created from the unconscious, which is another way of referring to the spiritual portal in the human mind. Therefore, poetry speaks to the 'unconscious' in people. The South African poet, Mzwakhe Mbuli, who is affectionately christened 'The People's Poet', because his poetry was for the marginalised people during the apartheid era, appealed to South African masses ideologically, politically and spiritually with his poems that decried racism, promised doom to the pernicious apartheid regime and most importantly, inspired in people a sense of being human and encouraged dreams and hope of freedom in the minds of the oppressed. Mbuli's poetry was littered with the subject 'God' as a means through which he could appeal to the psychological and spiritual sensibility of the people, thereby instilling in them a sense of worth and the idea that they were not lesser beings, as falsely purported by the apartheid system.

In this paper, art, which is an umbrella term for all forms of art, will sometimes be used to mean poetry.

\title{
The Case for (Okri's) Poetry
}

Endorsing Okri's most recent collection of poems, A Fire in My Head: Poems for the Dawn (2021), the publisher Apollo (2020) described Okri and his new work of poetry in this manner:

\begin{abstract}
A powerful collection of new and recently completed poems by Ben Okri covering topics of the day, such as the refugee crisis, racism, Obama, the Grenfell Tower fire, and the Corona outbreak. In our times of crisis, the mind has its powers. This book brings together many of Ben Okri's most acclaimed and politically charged poems.
\end{abstract}

In Percy Bysshe Shelley's A Defense of Poetry (1969), one reads that "poets [are] the unacknowledged legislators of the world"; poetry is seen as a force for good, for shaping society's realties and keeping politics in check (Shelley, Garland, Marquard \& Watson, 1969). Shelley fights against poetry being ignored. In his book of poetic essays entitled A Time for New Dreams, Okri writes:

Heaven knows we need poetry now more than ever. We need the awkward truth of poetry. We need its indirect insistence on the magic of listening.

In a world of contending guns, the arguments of bombs, and the madness of believing that only our side, our religion, our politics is right, a world fatally inclined towards war - we need the voice that speaks to the highest in us.

We need the voice that speaks to our joys, our childhoods, and to the Gordian knots of our private and national condition. A voice that speaks to our doubts, our fears, and to all the unsuspected dimensions that make us both human and beings touched by the whisperings of the stars (Okri, 2009:3). 
The above quotation should make an adequately convincing argument for the importance of poetry in the world, in the lives of people. Captured in it is the aesthetic, the cultural, the spiritual ("the highest in us"), the political, the religious and the personal spheres of life and the world. Okri also makes the case for poetry by declaring that poetry is significant in times of strife, captured aptly by saying that it deals or 'untangles' "the Gordian knots of our private and national condition" (Okri, 2009: 3). More pungent and rentable, given the global crisis of Covid-19 that has since put the world and human life adrift, is his saying that poetry is needed to deal with "our doubts, our fears and all the unsuspected dimensions" (Okri, 2009:3). Poetry appeals to the sensory, the intuitive in humanity, and this makes it a powerful tool to alter perception and to inspire thought. Gray (2009:2) opines that poetry has the power "to appeal to the sensory ('the magic of listening' encapsulated in the onomatopoeic 'wheels', 'glides' and 'stumbles') and the cerebral ('the awkward truth of poetry' alluded to in the implied contrast between the preoccupations of humans and the freedom of nature)". In the anthology of 'political' poetry that Okri compiled, he makes this case:

\begin{abstract}
... poetry is its own power, is its own terrain and universe and at its freest recognises no other. Poetry gets its own authority from the voice, from the self, from breath, from the cosmos, from the primal and source of freedom itself. Poetry needs no other power for it to be. It needs no other stage to exist except the ear and the eye, the listening heart. Politics is the manipulation of power in the structure of the world. Its territory is the world. This terrestrial monarch called power and this spiritual monarch called poetry are monarchs of realms that fundamentally compete for hegemony (Okri, 2018: xiii).
\end{abstract}

Key in the quotation is the idea that poetry has power, and that its power is spiritual in nature. This then supports the argument that poetry is a significant form beyond its aesthetic nature and function. It also pillars the argument of the current paper which is that poetry is a balm for the soul, a mental companion during times of strife. Lastly, it hammers home the validity of exploring Ben Okri's poetry to the development of insight into the interrelationship between poetry and spirituality, the significance of poetry in relation to the spirituality of people, especially in a time where the world is held hostage by a pandemic.

Birat fairly justifies why Okri's poetry should be explored by stating that:
His eclectic approach to writing has been the object of much commentary, as was made clear by some of the conflicting readings of The Famished Road (1991), in which he also included dimensions of African spirituality and oral culture. However, his poetry has received very little critical attention, in spite of the fact that the writer has often insisted on the central place occupied by poetry in his work. Okri is a suggestive poet and thinker, and his poetic oeuvre is loaded with suggested meanings and interpretations. And this paper will interpret Okri's poetry in relation to the reality of our times. (Birat, 2015:1)

Okri's poetry is vital in many ways, and deserves to be studied or explored, especially because he is a poet and writer whose thinking and writing are relevant to the times. "Poetry begins in us an inner dialogue. It suggests a private journey to one's truth" (Okri, 2019: 4).

Okri is a poet who is concerned and preoccupied with a number of ideas and issues. According to Birat (2015:1072), "The ideas that Okri has expressed through all the forms of his writingfiction, essay, and poetry-and particularly those relating to spirituality, creativity, and the future of mankind, have been scrutinized in some detail, although they cannot be seen as constituting a system corresponding to a specific ideology or even philosophy". This description suggests that Okri's writing is spiritual in the sense that like the spirit, it cannot be contained or claimed by one or two ideologies or philosophies, as it appears, Okri is enriched by many things - his writing bears testament of this. 


\title{
Poetry and healing
}

The act of writing is regarded by many as therapeutic. In his critical book, What is Literature? where the second chapter is entitled: 'Why Write?', Jean-Paul Sartre begins by asking and answering simple but thoughtful questions, prodding the reader towards seeing the significance of writing in this manner:

\begin{abstract}
Each has his reasons: for one, art is a flight; for another a means of conquering. But one can flee into a hermitage, into madness, into death. One can conquer by arms. Why does it have to be writing, why does one have to manage one's escapes and conquests by writing? Because, behind the various aims of authors, there is a deeper and more immediate choice which is common to all of us (Sartre, 1967:26 emphasis added).
\end{abstract}

The need for healing, either of the physical (the flesh) or emotional (the soul) aspect of our being, is what is common about human beings. Alexander Fleming's discovery of penicillin in 1928 has since been regarded by many as the most significant finding for the healing of bodily pain by the global health care fraternity. Thus, it can also be observed that our ancient ancestors' discovery of oral art, writing and the cave rock painting have made a deeply significant finding for the healing of the human soul (Gaynes, 2017; Tan \& Tatsumura, 2015; Derdarian, 2007). Poetry, especially dramatic poetry, is one of the art forms that is regarded as engaging people's emotions and bodies (Kaufman \& Baer, 2002). Aristotle regards poetry (a term that originally housed in its meaning all other forms of art) an important tool for Catharsis, which is a process of healing, or the taking out of one's emotional and mental system, that is, anything that bears toxicity. According to Anandawansa (2014:141), "The Greek term "Catharsis" has two principle meanings: purgation and purification. More specifically, the crux between the two meanings holds the notion of catharsis as a medical purgation of excessive emotions on the one hand, and the ceremonial purification of the body on the other". There are many studies conducted on the use of poetry to treat people with mental disorders and instabilities such as depression and stress. Rich (2007:422) argues that poetry is not to be idealised, especially because it is not a healing lotion, "an emotional massage and a kind of linguistic aromatherapy." Later in the same paper, Rich (2007) 'somersaults' and says that "when poetry lays its hand on our shoulder, we are, to an almost physical degree, touched and moved." The touching and the moving here, that poetry renders upon us is somewhat healing, or a going towards healing. Suggested in the 'touch' is the 'massage', the ironing out, the arousing of human emotions.

Leedy (1969) states the following:

... papers by different authors consider poetry therapy as treatment for persons with emotional disorders. Its use with the following is described: a psychotic patient, hospitalized schizophrenics, psychoneurotic in a mental health center, and disturbed adolescents. Also discussed are poetry as therapy and as a therapeutic art, principles of poetry therapy, the validation of poetry as a group therapy technique, and poetry as communication is psychotherapy. The use of poetry in individual psychotherapy and in a private mental hospital is described, as are poetry therapy in a self-help group, in a specialized school for the disturbed, and in a counseling center.

Reece (2000) cited in Raingruber (2004) opines that "poetry is phenomenology, a way of making sense of the lived experience of human beings, a conversation with one's environment, a way of giving voice to feelings individuals are not easily able to articulate". Poetry helps people tabulate the experiences of their lives because it affords people the opportunity to pause and ponder their milieu, thereby helping them to re-focus and re-examine their lives and redream his or her environment (Blake, 1990); poetry completes people's halfideas, thoughts and bestows them with epiphanies that alter their lives in ways they would not 
have expected (Ashbery cited in Blake 1990; Oates, 1978; Sartre, 1949). This is because poetry is punchy, pungent, introspective and contemplative. Through the unusual use of language, poetry presents people with the lens to hold a new way of seeing the world and understanding their lives. It is by engaging poetry, feeding off its rhythmic impulses of thought, feeling and seeing, that people are able to hold their experience and environments with a fresh and acute comprehension. Poetry has the power to tilt the angle at which human beings view the world and regard one another as people. Poetry can bring about the healing of social and political rifts, especially because it has the power to heal, through deep questioning, social maladies such as racism it has the ability to point out the 'lowest' in people, as well as the 'highest' in people.

\title{
Theoretical framing
}

This paper adopted the Hermeneutical theoretical approach. This approach is about the interpretation of a text in order to develop insight from that text. Gergen, Hepburn and Fisher (1986) cited in Patterson and Williams (2002:102) submit that "Hermeneutics originated during the $17^{\text {th }}$ century as an approach for interpreting biblical texts". Hermeneutics comes from the root word Hermes, which is the name of a Greek god, who appears in Homer's writing as among other things, a messenger of the gods. Hermes was also venerated and celebrated as a dream (imagination) god, god of roads (openness) and doorways, and a god-protector of travellers (explorers). The finding of fortunate or treasure was attributed to him, and he was ultimately dubbed the god of fertility. This etymological conception of the word/name Hermes illustrates some of the key features associated with the derivative concept of Hermeneutics as it outlines: exploration (travelling/roads), interpretation (doorway), imagination (dream), messenger (the bringing of insight). Simply defined then, Hermeneutics is the art of interpretation (Abulad, 2007). There is what is called "macro" and "micro" Hermeneutics (Dorairaj, 2010:105). According to Abulad (2010:11), "Hermeneutics - the word goes back to a name, Hermes. Who is Hermes? Among the earliest references to him is made by no less than Plato in the dialogue, Cratylus." Abulad goes on to offer an elaborate and dramatic definition of what Hermeneutics is:

\begin{abstract}
Somewhere in the dialogue, Plato (or Socrates) speaks more precisely of Hermes, as follows: "I should imagine that the name Hermes has to do with speech, and signifies that he is the interpreter, or messenger, or thief, or liar, or bargainer; all that sort of thing has a great deal to do with language. As I was telling you, the word eirein is expressive of the use of speech, and there is an often-recurring Homeric word hemeisato, which means he contrived. Out of these two words, eirein and meisastai, the legislator formed the name of the god who invented language and speech, and we may imagine him dictating to us the use of this name. O my friends, says he to us, seeing that he is the contriver of tales or speeches, you may rightly call him Heiremeis. And this has been improved by us, as we think, into Hermes. Iris also appears to have been called from the verb to tell (eirein), because she was a messenger." (Abulad, 2010:12)
\end{abstract}

In light of this, Hermeneutics can be aptly summarised as a theoretical approach which involves the interpretation of language used in a text thereby manufacturing and signifying insight and understanding of a text.

Patterson and Williams (2002) have this to say about Hermeneutics:

Hermeneutics maintains that much of our everyday experience occurs in the ready-to-hand mode of engagement, as practical activity in which actions and emotions are structured by (1) the situation, (2) cultural practices, and (3) current projects and concerns that include habitual responses that are so familiar they are taken for granted.

From the above quotation, Hermeneutics can then be conceived as an approach that enables the interpretation of a text with the sole objective of coining insights on the relevance (with the 
time and in time) of the text being interpreted. This paper then follows the theoretical mould of the Hermeneutical Approach since it provides a fertile ground for the development of insight on spirituality embedded in Ben Okri's poetry as an aspect that makes his poetry relevant during the troubled times of Covid-19. Interpretation and interpretability are the basic tenets of the Hermeneutics theoretical approach, especially when one deals with literature, as it encompasses many other approaches to the study of literary texts (Landan, 2014; Brandom, 2004). This approach is acutely ideal as it provides for an interpretive and insightful readerresponse, which is a fruitful way of generating new ideas, meaning and understanding of a literary text (Muganga, 2016; Noorderhaven, 2000).

\title{
Writing for Hope
}

Hope is a philosophical concept that drives the lives of many people across the world. Religions of the world have made hope (or the promise of a greater future) the kernel of their gospels or teachings. Hope is defined by the Cambridge Learner's Advanced Dictionary as "something good that you want to happen in the future, or a confident feeling about what will happen in the future" (Cambridge Learner's Advanced Dictionary, 2005:616). Aquinas cited in Smith (2010:4) defines hope as 'a movement of appetite aroused by the perception of what is agreeable, future, arduous, and possible of attainment.' According to Locke (cited in Smith, 2010:4), 'hope is that pleasure of the mind, which everyone finds in himself upon the thought of a probably future enjoyment of a thing which is apt to delight him'. For Milona (2020:100), "Hope is often contrasted with despair and fear. The word 'despair' indicates an absence of hope." Scioli (2007:136) captures the importance of the virtue called hope in the following manner:

\begin{abstract}
If you were to read the Bible from cover to cover, you would find that the word "hope" appears over 180 times or approximately once every seven pages. Christians, however, are not the only ones sustained by hope. Buddhists, Hindus, and Jews as well as the followers of Mohammed, the African Ifa, Native Americans and the Australian Aborigines draw their "spiritual light" from hope-oriented belief systems.

Hope has been hailed by thinkers of every age from Aristotle to Marcel. It has been endorsed by the spiritually-minded as well as the most atheistic philosophers and scientists. Practitioners of every healing art have prescribed Hope. (Scioli, 2007:136).
\end{abstract}

Hope is a very important concept, virtue and 'energy' in human affairs. During terrible types such as the era of the Coronavirus pandemic, people hope for an end of the pandemic, people hope that things will get better in the future. As Scioli (2007:136) puts it, "Hope is especially important in dealing with stress and adversity." During times of adversity or global or national tragedies such as war and economic depressions, governments find themselves responsible for instilling a sense of hope in people to ensure that they do not despair and fear. Presidents deliver oratories which are set out to mobilise the national psyche of the people into hope and hoping. In South Africa and elsewhere in the world, leaders carried out the reading of speeches that sought to discourage despair and a fearful response to the pandemic and the lockdown. The speeches, which were written in an artistic style, served the purpose of inspiring hope in the people. Giving hope to people who are at their lowest spiritually, is art's function.

Okri's poetry is rich with the theme of hope. By implicating the theme of hope in his poetry, Okri writes for deeper and essential purposes of uplifting the human spirit. Okri's poetic oeuvre is in fact imbued with optimism, which is related to hope; he writes for hope of a better life for the African people, a greater future for all humanity. His poem 'An African Elegy', for example, defies the meaning and purpose of an 'elegy' (which is mourning), and is a good example of writing for hope. In the first stanza of the poem, Okri writes:

We are the miracles that God made

To taste the bitter fruit of Time. 
We are precious.

And one day our suffering

Will turn into the wonders of the earth.

In this poem, Okri acknowledges the pain and suffering that human beings (especially Africans) are living in and enduring. The poem in fact, mingles pain, suffering, distress and tribute and hope. Captured in line 1 of the stanza above is the idea that human beings (Africans in the context of the poem) were created for a greater and divine purpose. Okri goes on to offer that though created for a greater good, human beings will go through trials and tribulations, tragedies, wars, starvation and oppression. All these undesirable happenstances that constantly accompany life are captured by the "bitter fruit of Time" in line 2 of the poem. Coronavirus is a bitter fruit of the $21^{\text {st }}$ century, and the modern human being has come to 'taste of it'. Though tasting the "bitter fruit of Time", Okri's paradoxical 'elegy' impresses (in) and reminds the reader that "We are precious" (Okri, 2015). It is the kind of poetic reminders and declarations such as the one captured by Okri's poem that weave a fabric of hope when people are faced with pandemics, especially when there are prophets of doom shouting that we are being punished by God or the gods with plagues and viruses. Okri believes in the future, and one which is worked in the alchemy of human thought, dreams and ultimately, deeds.

This is what Gray says about Okri as a man who hopes for a better future:

In the enormous angst of unresolved issues of materialism, of loss of faith in a higher order as well as indigenous knowledge systems - of the defeat of nationhood, the primordial sap, global warming, the Fourth Industrial Revolution, the Covid-19 pandemic and general disillusionment of the twentyfirst century, the study of Okri's works (poetry) hints at 'how the future can have a future'. (Gray, 2020)

\section{'The Freedom Artist'}

In an overture to the story of his most recent allegorical novel, The Freedom Artist (2019), Okri writes: "It is written in the oldest legends that all are born in prison. This prison is all they know. Literature describes life in it. Religions hint at redemption from it" (Okri, 2019:3). The advent raised the high walls of the prison of healthy crisis, death and the feeling of being bound. More than anything, the people wanted to be rid of Coronavirus, which is akin to wanting to live in freedom rather than in the prison of a global health crisis, which was made worse by lockdowns that took effect all across the world, as a strategy to curb the spread of the virus. People's movements were restricted. People all over the world were barred, for their own safety, from participating in recreational activities, the accessible purchase of alcohol and smoking, which many people rely on to relieve stress and deal with socio-economic issues such as unemployment. The Coronavirus pandemic includes a prison. Freedom in all its dimensions is one of the recurring themes in most of Okri's writing and poetry. His other novel, Starbook (2007), tells a fabulous tale of a prince who falls in love with a maiden in a mythical land, where a golden age is ending (Okri, 2007). The theme of freedom appears where the prince questions his father, the King, about the inhumane condition in which a certain kind of people live, these people who are slaves, find themselves in the favour of the prince who questions and speaks out for their freedom from slavery.

Freedom is one of the most sought after and wrought conditions in human affairs. People have always sought and fought to be free from many kinds of oppressive systems and situations. Africans, for instance, have fought and sung for freedom under the brutal and discriminatory colonial and apartheid regimes. Oppressive systems or situations always strike the gravest and hardest blows on the human mind. Understanding this crude effect of oppression on the human mind, the Jamaican reggae legend, Bob Marley, sang in his, Redemption Song [which Okri included in an anthology he compiled entitled Rise Like Lions: poetry for the many (2017)]: "emancipating yourselves from mental slavery" (Marley, 1980). The Penguin Dictionary of South African Quotations compiled by Jennifer Crwys-Williams (2008:131) cites Jesse Jackson, who offering a direction on the way of being free, said of freedom and being free, 
"Strong minds can break chains". Minds need strength, a nudge, a push to break chains and be emancipated from mental imprisonments of any sort. Freedom, which is akin to creativity, is a central preoccupation in Okri's poetry, as both a theme and an 'abstract mood'. It is for the condition and concept of freedom that Okri poeticises too. In a poem entitled 'Obama' in the most recent collection of his poems, Okri tempers us by saying:

\section{... But we have to do the work ourselves \\ To change the structures so we can be free. \\ Freedom is not colour; freedom is thought.}

An attitude, a power of spirit,

A constant self-definition. (Okri, 2021:51)

What Okri is capturing and offering to us here is that we have the power to be free from any kind of oppressive structure. Key is his description of freedom as "an attitude, a power of spirit". With this, Okri is in fact saying that people should work out the attitude of freedom in their minds, souls; they should work for the attainment of a positive and affirming mental state of being free. An attitude is basically a positive mind-set; and this is what Okri encourages people to catch, and especially in dealing with situations such as the Covid-19 pandemic, which can 'cast chains upon the mind'. By 'chains', reference is made to the stress, trauma, depression and hopelessness, and all the other mental illnesses and instabilities that a 'lockdown' and the loss of loved ones and jobs can cause in the lives of a people living under an unexpected tragedy such as the Coronavirus. Okri also ignites the attitude of defining oneself, and refusing to be defined by others, even situations such as the one that the world is now hurled in - the Coronavirus pandemic situation.

Poets are alchemists of thought, ideas and perception. Through working with the 'gold that is language' and expression, poets alter how people conceive and react to reality. Okri is that type of poet, who works with thought and believes in new thoughts and ideas that could alter "the way we think" (Okri, 2021:48). In the poem 'Obama', he offers this:

They change the world best who

Alter the way we think.

For our thoughts make our world. (Okri, 2021:48)

Interesting in the quoted lines is the pronoun 'They', and it is interpreted as referring to poets, such as Okri himself, whose poetic offerings to the world help shape our thinking or our reality. There is also the use of verbs such as affect/alter/inform/challenge/guide/inspire, which are meant to alter the atmosphere of our perceptions, conceptions and reactions to the world and quotidian reality. This is because 'they' give us alternative ways through which to see and think the world. By so doing, it is opined that "thoughts make our world" could therefore be interpreted as, the meaning of what we see in the world, is the product of our thinking. Consequently, it could further be said that every ounce of apparent freedom in the world is as a result of peoples' thinking and subsequent working out conditions that breed freedom. In fact, the following lines confirm this interpretation:

Some think it's our deeds;

But deeds are the visible

Children of thought. (Okri, 2021:48)

Okri uses a metaphor to describe what deeds are or how they come about, and avers that they are birthed by thoughts. Metaphor is mixed with personification here, where he gives both thought and deeds the qualities of a parent or a mother. This is to say that thought is fertile enough to conceive or manifest deeds, and deeds, like children, have the potential of growing and maturing, thereby bringing about great changes in the world. The word 'thought' is loaded with possibilities. Thoughts can release great ideas and inventions. It is at a time of the Covid19 pandemic that Okri encourages the conception of thoughts in the reader. The 'engineers' 
of the American Civil Rights Movement, such as Martin Luther King Jr. fashioned the idea of movements in the moment of brave thinking and inspired thought (Ulafor, 2020).

\title{
The theme of consciousness
}

Frequently, neither spirituality nor religion figures in people's consciousness until there is a major event in their life that causes them to reflect (Lepherd, 2014). Okri's poetry has the potential, agency and urgency to cause people to consider the essence of consciousness during the Covid-19 pandemic. This is because his poetry is thought-provoking, it nudges and ultimately awakens people's consciousness. Gray (2020) regards Okri as an inimitable conceptual artist; his writing urges us towards upliftment, pointing the way to a higher consciousness for the well-being of humankind and planet earth. Additionally, Gray (2020) sees Okri as a conscious artist whose writing demonstrates the complexity and transformative power of African culture and thought. Okri's poetry does not just touch a reader's emotions, it heightens them spiritually. It touches the emotions of the reader with an enlarging effect, and that is the power of poetry. It poses big and important questions to the world, the human race, and our times, and the political and social status of the world.

For Okri, consciousness is 'a-wakefulness', it objects to tendencies of sleepwalking through life, oblivious to the big and miniature things of life and being human. Consciousness for Okri's is a journey, which all human beings must undertake to discover or recover themselves, or something about themselves. Okri demands of his readers to be part of what he has written. In a way, he demands an 'a-wakefulness' from the reader. Birat (2015:1072) offers this general view of Okri's work:

\begin{abstract}
While the essays and the poems can be seen as illuminating each other in a form of cross-fertilization, Okri's tendency to explain his ideas and theories about art and its relation to life, culture, and history may also leave little place for the reader's imagination, in spite of the writer's insistence on the importance of the reader's participation in the act of creation.
\end{abstract}

Consciousness for Okri is not just a theme, but an application that the reader must use in reading his work.

\section{Transcendence}

When a people's reality is threatened, a transfiguration of their perception and being is the dream, the desired objective. Artists and poets have always been preoccupied with the concept of transcendence. When the word 'transcendence' is mentioned, the word 'reality' shows up as well, for the two are connected and associated. If literature is examined and interpreted through the lens of immanence, a new kind of divine message can be read which could shape our destiny (Goyal, 2016). Immanence has to do with a person's belief that they are inherently part of something, and inherently existing in a place which could either be physical or spiritual. Human beings believe and see that they are part of the physical world and most of them also believe that they are part of a spiritual place, and that they are inherently involved in the spiritual place and space as well. There are many people who believe that the physical "place" is in constant contact with the spiritual place. Religions stand on the belief that the divine, the Deity, is present in the universe and in time (place and space). Okri's writing boasts the theme of transcendence, which is intricately linked to reality and spirituality. From some of his novels, such as the purely imaginative one, Astonishing the Gods (1996), which is set nowhere else but in the mind, and captures the theme of transcendence and selfdiscovery in a poetic and apt manner, to his poetic essays and poetry, Okri is evidently preoccupied with writing about the theme of transcendence. This can be regarded as the reaching of the highest way of being, or simply refusing to wallow in crisis and pandemics because you believe that you belong to a higher force. 
Okri is also preoccupied with the concept of transcendence in his poem 'An Africa Elegy', especially in line 1 where he declares that "We are the miracles that God made" (Okri, 2015). This line can be fittingly interpreted as suggesting that we are beyond our problems; because a miracle is a divine possibility, that can turn around any state of affairs. Moreover, this line boasts that human beings are not lesser creations or beings, but that they are invested with spiritual force and the privilege of belonging to a greater force or spirit (God). This resonates with the opening of his fabulous novel, Starbook, where declares: "There is an ancient saying in the village that my mother used to tell me. They say it is not who you are that makes the world respect you, but what power it is that stands behind you. It is not you that the world sees, but that power" (Okri, 2007:3). This means that though mortal beings are not immune to contracting and dying from diseases, human beings still possess a transcendental quality in them. Therefore, reading Okri's poem in a time of crisis could instil a stubborn attitude of resilience and hope because Okri's writing, as Gray (2018:17) puts it, "prods us towards the light".

The concept or theme of transcendence in Okri's poetry can also be read and interpreted in his other poem called 'Talisman for the Journey', where he writes:

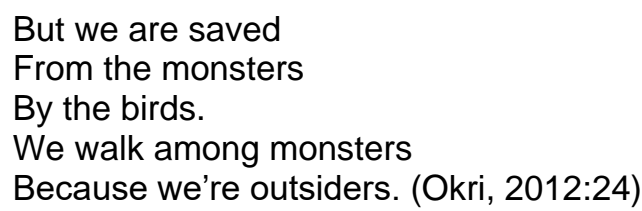

"Birds" are symbolic here. Flying is a vertical motion or action, a going higher. Therefore, one can think of the legendary bird, the phoenix, which is symbolic of the power to transcend tragedy, malady or death (Nigg, 2016). Birds are also representative of spirit or spirituality, i.e. the dove that brought Noah the leaf of confirmation that the flood had ceased, and in the baptism of Jesus where a dove appeared representing the Holy Spirit (Gero, 1976). According to Bierdermann (1989:39), "Birds symbolize the power of people to speak reflectively and lead them to think out many things in advance before they take action. Just as birds are lifted up into the air by their feathers and can remain wherever they wish, the soul in the body is elevated by thought and spreads its wings everywhere." Symbolically, the reader can also think of the 'birds' that Okri speaks of as people (leaders), who have a keen sense of vision to lead and bring about solutions in a troubled world. Also, one can think of Okri's salvation birds as being imagination, hope or even dreaming, which keep people's spirits both brave and positive. These are attributes that give human beings the capacity to overcome and transform.

Implied by Bierdermann (1989) here is that there are those thoughts that elevate the human soul. Okri's poetry possesses those thoughts, which inspire transcendental reflective thinking and holds the perception that we can be saved from pandemics, especially because we are not really of the physical place, which is forever haunted by plagues, rather, we are "outsiders". Transcendence or to transcend could also mean the turnover of one's mind, mental attitude from a negative side into a positive side, one that hopes and believes in a better future, especially in the face of a time and place riddled by a pandemic. Transcendence is also associated with transformation (Cobb, 2001).

Gray (2020) regards Okri as a conscious artist whose writing demonstrates the complexity and transformative power of [African culture and] thought. This resonates with Okri's maxim about freedom, where he observes "only free minds can create a free world", whose axis can be flipped over on its head to capture that which only conscious minds can inspire in the consciousness of other minds, a consciousness that one possesses a transcendental power. Gray (2020) remarks that in Okri's writing there is to be found the power of revivification which comes from the reminder of the powers that are latent in all human souls. The evidence of Gray's above remark can be harvested in Okri's 'An African Elegy', where he says: 
And there is surprise

In everything the unseen moves. (Okri, 2015)

The "unseen" entails the latent spaces or places around human beings, the spiritual spaces. And everything in which the "unseen" resides and, transcendental powers move, is basically the spiritual nature of a human being, and God. Therefore, Okri's poetry carries the faith that human beings are not really on their own, for in their existence, a deity, a spiritual force, is inherently involved. Another poem of Okri called 'The World is Rich' implies the same sentiment of human beings being inherently supplied with the richness of transforming or transcending into something higher. Okri writes in that poem:

\author{
They tell me that the world \\ Is rich with terror. \\ I say the world is rich \\ With love unfound. \\ Inside us and all around. (Okri, 2012:35)
}

For Okri, love is a spiritual force, and it is one of the central aspects of human nature that his poetry speaks for/of. Okri's poetry proffers that human beings should exude and exchange love in their living. Love is a force with which Okri believes the world can be transformed, especially if we find it "inside us" and see that the world is indeed rich with it. This is Okri's dream of transcendence, and it is not beyond reach for us to hold and fight the terror in the world. He also teaches that human beings must transcend their class, tribe, race and religions. This is the richness that Okri speaks of. The poem quoted here, in the words of Gray (2020), provokes reflection and imperceptively leads to inner transformation, or inner transcendence. Okri goes on to say, in the poem:

\author{
There is terror in the air. \\ And we have put it there. \\ We have made God into an enemy, \\ Have made God into a weapon, \\ A poverty, a blindness, an army. (Okri, 2012:35)
}

Okri is simply challenging people to reconfigure the toxicity of their ignorance, which has been caused by racial hatred, polar political ideologies, and many other classifications that bring about divides between people. He is tempering people to remember the power they possess. As much as this power can be used to destroy or poison ("the air"), it can also be used to create, build, re-dream or re-imagine the world, and to direct or re-direct. This, in a way, is the transcendence of a people's unpleasant condition in which they currently live. Furthermore, Okri prods humanity towards a reconciliation with a marred connection to their source of transcendental power, the divine, which, according to Okri, is currently twisted into something negative and destructive, whereas it is originally meant for the empowering of human beings. This connection has been marred by people's insistence on hating one another (racism), material success, and the loss of faith as a result of denying the existence of a spiritual realm beyond the physical. According to Okri (2019:162), the reason for this is that "Material success has brought us to a strange spiritual and moral bankruptcy".

Okri declares once again in a poem entitled 'More Fishes than Star' in Wild (2012):

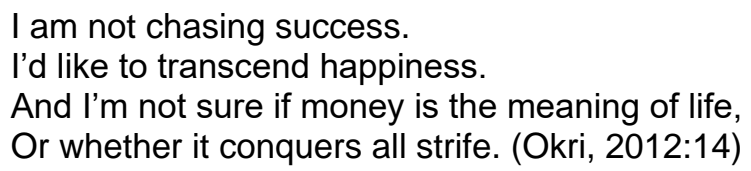

Here, Okri submits a clear belief in the supremacy of transcendence over happiness and money, which he does not belittle, but points out that they are not enough. In a way, Okri is saying that human beings must seek to go beyond the earthly or physical plane of life, outsider 
definitions, single-coloured lenses of perceptions, racial discrimination, social stratification, and political ideologies and religious notions that demonise other notions different from them. Teimouri posits that Okri's writing is significant to make us understand "that we share the same fate and a common destiny demands a transcendental vision of the temporality of our existence, one that is devoid of selfishness and self-interest (Teimouri, 2012:11).

\section{Influences of Buddhism in Okri's poetry}

Okri is a poet enriched by multiplicity, cross-cultural understanding, the appreciation and respect of all the religions of the world. As result, some aspects of the teaching of some of the religions of the world permeate his poetry, and his writing in general is enriched "by as many things as possible" (Guignery, 2015; Okri, 2015). There are aspects of Buddhism in Okri's poetry, a religion whose spiritual inclination and aspiration are transcendence over illusions, suffering and the insatiability that is brought by excesses. Okri, like the Buddha, aspires and inspires us to master the art of living (Rowell, 2014; Okri, 2010). Okri meditates through his poetry, and invites the reader to feast on his meditation. This is evinced in the same poem quoted in the previous section:

I am not chasing success.

l'd like to transcend happiness.

And I'm not sure if money is the meaning of life,

Or whether it conquers all strife.

I ain't been on a holiday for some time,

And I don't think that's such a crime.

I sit still, like an oak tree on a hill. (Okri, 2012:14)

Here, Okri is making an inspired allusion to Buddhism, and the Buddha, who chose to leave his home of luxury and "success", wealth, to go and "sit still" and meditate under the Bodhi tree, in an attempt to transcend and enter the "window" into enlightenment; he wanted to "conquer strife" (suffering). In this poem, Okri is in fact inspiring the absence of hysteria in people, and encouraging meditation, which is partaken as a means to balm the human soul, to channel or gather one's energy into focus, so as to be in harmony with the world and all living things. The "oak" takes the place of the Bodhi tree, and both trees are symbolic of steadfastness. Still, the oak tree could be interpreted as symbolic of an attitude of mind to remain rooted in hope, or positive thought, especially amid the raging storm of the Coronavirus. To take another variation, the "oak tree" takes the place of the tree of good and evil in the Garden of Eden.

In the poem 'Obama', Okri describes what freedom is, which resonates with one of the trainings or practices of Buddhism, which encapsulates the aspiration of developing freedom in one's mind (thought) - Samadhi. The Samadhi practice or training, of the three practices in Buddhism means or has to do with "Concentration, meditation, mental development. Developing one's mind is the path to wisdom which, in turn, leads to personal freedom. Mental development also strengthens and controls our mind; this helps us maintain good conduct" (Saisuta, 2012:2).

In his Epic poem called, 'A Mental Flight', Okri exudes this practice showing that Buddhism percolates his poetry:

Our future is greater

Than our past. So

Far we have mostly misapplied

The powers of the mind.

We have under-applied

The wonders of the human soul.

The mind that created pyramids. (Okri, 2021:61) 
Okri is calling for the refiguring of how we ought to use our minds. He makes a challenging claim that we have lost the grip on how to apply our minds and souls, something the Buddha mastered so as to gain deeper insight of life and living. Okri writes about suffering, which features in Buddhism, in what is called the Four Noble Truths. Of suffering, Buddhism says: "Suffering exists: Life is suffering. Suffering is real and almost universal. Suffering has many causes: loss, sickness, pain, failure, and the impermanence of pleasure" (Saisuta, 2012:2). And of suffering, as if echoing Buddhism's optimism, Okri writes in his most famous poem, 'An African Elegy':

And one day our suffering

Will turn into the wonders of the earth.

This resonates with our times, where Covid-19 is wreaking havoc in the lives and minds of all peoples across the world. Gray (2020) perceives Okri's as poet-seer of our times, and aptly opines that Okri is a visionary symbolist who enlightens humankind. She further says Okri's works interrogate existence - what being human signifies. Okri's poetry shows aspects that convey that he is partly, among other things, influenced by such spiritual teachings as Buddhism. This interpretation of Okri's poetry, and perhaps the man himself as influenced (a word he does not like) by Buddhism, can be summarised by inviting Gray's (2020) view, which is that Okri is a 'mystic', a 'contemplative artist'.

\section{Race, identity and spirituality}

Through a book or a poem, one can reach millions, even billions of people across geographical, political, religious and cultural boundaries. Writing a book or a poem is like a flying bird that is always criss-crossing the world. Through a book, a writer spews his or her joys, celebration, suffering, confusion, questions and understanding. A case in point is James Balwin's Go Tell it on the Mountain (2016) which decries the racial bias in America, the plight of black people in America. Through a book, one can inspire in other people across the world sympathies or solidarity or outrage and protest against injustice and prejudice; a book can make other people aware of others' sufferings. A book or a poem questions, clarifies, exposes and challenges reality because it has the power to capture and scrutinise reality (Okri, 2019). And through the writer's expression, readers are made to realise social phenomena that they otherwise would not have realised under 'normal' circumstances. Anandawansa (2014:146) offers this view:

Catharsis dawns the human mind into realization. This realization is arrived at by reasoning and by knowledge, and knowledge is valuable. Not only does it enable us to depend on our beliefs, but it also enables us to believe in the beliefs of others.

Racism is a social malady. It has caused a deep rift among human beings across the world. Racism has melted and weakened the bond and commonality that human beings ought to share. All across the world, the war between identities is raging. Even religions are feeding this war of identities. But Covid-19 has somehow quietened the scuffle between worldviews and identities, because it has affected all human beings, irrespective of one's race. Covid-19 has compelled many people across the world to begin to see each other in a different light, as one thing, a spirit. Coronavirus has ridiculed, and somewhat nullified the physical differences that people have created among themselves. In Okri's recently published collection of poems entitled A Fire in My Head: Poems for the Dawn (2021), there is a very interesting poem called, 'On Race'. The poem ridicules racism as ignorance and the racist as ignorant. The central premise of the poem is the submission that human beings are the same, spiritually, and must be treated equally. Here is a sample from the poem:

ignorance thinks there's black and white

ignorance thinks there's them and us ignorance thinks of outsiders and insiders 
ignorance thinks about skin and not heart ignorance thinks one race is better than another ignorance thinks people should be kept apart ignorance thinks nothing unites us all (Okri, 2021:62)

These are intrepid and incantatory lines. The reading of these rhythmic lines invokes the casting out of the virus of ignorance which imprisons people of the world in hatred, discrimination and self-isolation caused by all the repellent labels that they put on each other. Covid-19 has no eye for pigmentation. Covid-19 has affected and can infect us all. The Coronavirus has kept us all 'inside' curfews and the mutual fear of death, and ultimately, the fear of extinction. Through this poem Okri inculcates in people that 'skin', 'pigmentation', 'appearance' is 'useless' compared to the 'heart', or spirit, the basic substance that is common in all people. Covid-19 has affected the rich and the poor alike, the short and the tall, the black and the white, the homeless and those sleeping in mansions; it has reminded humankind that they are together in this life, they are one and inextricably linked - the pandemic is symbolic. The virus has brought all peoples together, it has united them in fear, death, hope for healing and survival. Okri's poem inculcates in people the basic human philosophy of oneness. This poem has the power to inspire in people the ability to "image themselves into other people places", other people's suffering (Rowling, 2008). This is important because through imagining oneself as being in other people's suffering and realities, one can contribute to the alleviation of their suffering and contribute towards altering or transforming the people's reality (Arber \& Gallagher, 2009). This is vital because it can cause people to reconnect to the common thread of love that runs through all human beings. Aid workers, donors or philanthropists and charitable people do so because they imagine and see the suffering of others. This is called moral imagination (Arber \& Gallagher, 2009).

This poem was in fact inspired by the gruesome murder of George Floyd, which has since sparked outrage across the globe. The poem captures the idea that human identity is a collective one, guided by the sense that we are the same spirit. It revivifies the reader's sense of being (Gray, 2020). Okri's poetic impulse offers the idea that we can transform our world if we destroy the racial lines that exist between us, especially now with the Coronavirus, which can be regarded as an equaliser as it knows no colour or class, and has taught humanity the lesson that we are all the same, therefore, we ought to unite, beyond our colour lines and social stratifications. According to Okri (2019:5), "Poetry returns us to the surprise of our similarities".

Okri's poetry, among other issues, has a central theme of unity or oneness, of a bridging. It resonates with the poetry of other poets like the German poet, Rainer Maria Rilke (a poet committed to the theme of spirituality in his poetry), whose poem 'Silent Hour' speaks to the idea that we are all responsible for one another's freedom, safety, dignity and sense of belonging.

In another poem entitled 'Breathing the Light', specifically based on George Floyd's demise, Okri criticises many issues that poison our times, and racism features in the poem as a classic theme of the world's problems. Okri conjectures on George Floyd's childhood days and paints for the reader a picture of the general life that black people, like Floyd, are subjected to in their communities, a life which more often than not, leads the black child to death. Okri writes:

\author{
maybe all you saw \\ were the final moments \\ of your leap, when \\ on the school team, \\ you were going to touch \\ the sky and touch \\ the world; your leap \\ back then, how full \\ of promise, full
}




\author{
of the power to help \\ a team win. Life \\ afterwards was a long \\ fall into the abyss \\ of America, where \\ to be black is to make \\ an early pact \\ with death, not your \\ own death, but the death \\ that's waiting for you in \\ the blackness of \\ america. (Okri, 2021:121)
}

This poem criticises racism in America. The poem also criticises police brutality, a phenomenon now 'normal' in the U.S (Okri, 2021; Birat, 2015). Okri conveys his disappointment with America's constant injustice against black people, especially at a time when human beings ought to ally their oneness against a common enemy, the Coronavirus.

\title{
Okri's use of language, symbolism
}

Maharsi (2016) defines literature by marrying it with language, and opines that literature is viewed according to a range of characteristics such as being excellent, aesthetic, creative, imaginative, expressive, valuable, and universal. In his critical book called Literary Theory: An Introduction, Terry Eagleton submits that: "Perhaps literature is definable not according to whether it is fictional or 'imaginative', but because it uses language in particular ways" (Eagleton, 1983:2). Language is a tool. Language is a mirror in which the world and human life are reflected. Language is an amplifier of what human beings dream of and want to achieve. Language is a flexible signifier. Through its workability to express human feelings and thought, and to represent world issues aptly, creatively and captivatingly, language makes what is produced through literature valuable, as it makes it possible for literature to present compelling arguments and interrogations of society and politics and human behaviour; literature's language initiates debates around some of the most nagging issues of the world in the most fruitful and powerful way than does the mundane, every day speech one hears. Literature and language are like the 'nail and the finger', inseparable - like the sky and the blueness thereof.

Language is very important is human affairs. Language has both the positive and negative power to shape and influence people's lives. Language, through words, has the power to lift or lower a person. Okri states:

\begin{abstract}
Words do collect in us anyway. They collect in the blood, in the soul, and either transform or poison people's lives. Bitter or thoughtless words poured into the ears of the young have blighted many lives in advance. We all know people whose unhappy lives twist on a set of words uttered to them on a certain unforgotten day at school, in childhood, or at university. We seem to think that words aren't things (Okri, 2014:71).
\end{abstract}

The above quotation is an adequate annotation of the critical significance of language; it is a fitting semantic 'notation' of what could be said about the impact that language has on a person. It should be and understood and applied so that people should use language to lift, transform, inspire, love and positively shape themselves and those around them, and not to destroy. The language of poetry is a rich one, stocked with metaphors, imagery, paradox, the power to animate the inanimate, the capacity to make use of contradiction and irony to produce deep insight and the freedom to use language in a way that many other forms of writing could only wish to. In his essay that was meant to justify poetry as a significant art form, Shelly (1969) cited in Hogle (2006:145), defines poetry "as beginning when the most primitive person uses 'language and gesture' to produce 'the image of the combined effect of . . . objects and 
his apprehension of them'". Hogle (2006) then describes the language of poetry as being metaphorical.

Okri once said that 'language is power, and power is politics' (2013). Jowitt (2016) cited in Chikogu and Ofuani (2012:142) expounds that "Okri's language, like Tutuola's is magical but in a quite different sense, it is in fact quite sui-generis". Okri's language is filled with the energy that aspires to temper the regaining of what Gray (20009) terms the "Edenic" state of affairs in the world. This can be seen in Okri's poem, 'The Unknown Hour', where he writes:

\author{
There was no time \\ in the garden. \\ Neither clocks, nor necessity, \\ Nor referendums presided over \\ Our ancestors' temporal stay. \\ History, some say, is the secret \\ Effort to get back there. (Okri, 2021:21)
}

Okri's language is that of dreams, a language that enchants, that dreams forward, and that sometimes pauses and then, "its boat beats backward" (Okri, 2015), as if to say, "what we are dreaming of as a future, which is generally known to be ahead "beyond the seven mountains, with one concealed behind the other" (Okri, 2012), is in fact a past, a place in history (Eden), where our origins lie'. The poem, 'The Unknown Hour', which also makes reference to Britain's dream of exit from the European Union (the Breixit Referendum), strikes me as relevant to the seemingly unrelenting "unknown hour" of the "unknown" enemy, the Coronavirus, of which many said was the beginning of an end, the coming back of the Messiah or a return to the "garden" - cried out Christian evangelists (Dein, 2021; Knorr, 2015; Aldrovandi, 2014; Watch, 2012). The Eden that Okri's poetry dreams of is really the coming together of people of the world - so, Okri's language dreams of and breeds the idea of unity, and speaks for world peace amongst all the races of the world. Okri's use of language is lyrical, idiomatic, it is enriched with insightful and thoughtful maxims. An example of Okri's unique lyricism is captured by his poem in Wild (2012) entitled 'The Screamer', a poem framed by the lack of a rhyme scheme. Okri's lyrical beauty is framed and inflated by the imagery that juts out as he captures issues of our times. Here is a sample:

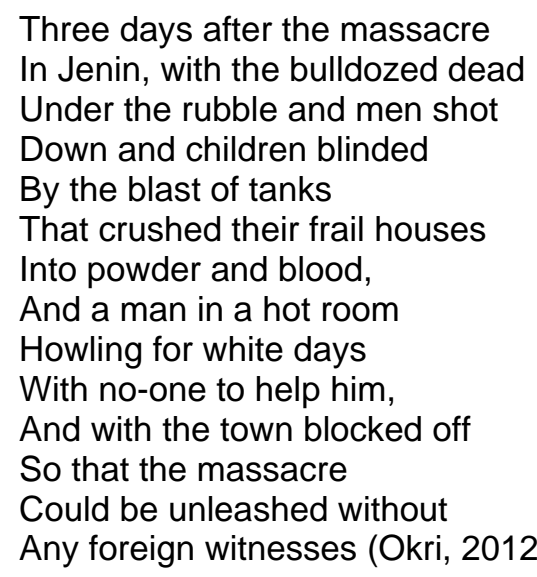

The above extract evinces an unrestricted flow of the poet's lyrical thought, which creates intense images. Okri's lyrical finesse quickens the reader's heartbeat, thereby arresting the reader to be one with the poem, and immersing him or her in the message, and consequently transforming the reader through the poem's core message. Okri's lyrical force captivates, enchants and leaves one in an almost vertigo sensation, as if the poem has taken a life of its own upon the reader; it takes the reader into the realm of the poem. 
According to him (Okri), in an interview with Rowell (2014), his language really boils down to one word, 'Arcadia', which is akin to 'utopia'. There are many words in many languages, but there is only one word known for literature. That word is "Arcadia." Some would choose "utopia," some would say "Eden" and that is problematic (Okri in an interview with Rowell, 2014:216). This word "Arcadia", a title of his novel, which describes Okri's language, is a dream, and he says of it: "We are largely defined by the quality of our Arcadias (dreams)" (Rowell, 2014:216 emphasis added).

In a world riddled by a pandemic, people need a new language with which to react, relate and image or re-image the world. In a world threatened by possible extinction, people need art, poetry to empower them with a language that could instil in them a sense of courage, thereby quietening hysteria. Okri's poetry is layered with the gold of a metaphorical, magical, symbolic and forward-thinking language, and this makes it a relevant feast for a world plunged in nightmares. Here is how Okri's metaphoric language that uplifts, is enshrined in his poem ('Breathing the Light') which is inspired by the George Floyd incident:

\author{
there's no poetry \\ of change greater \\ than when the world \\ see at last that \\ it can be free \\ free to breathe the light that \\ keeps the republic alive. (Okri, 2021:126)
}

The "light that keeps the republic alive" here could be seen as a metaphor for love among people of different races; it could also mean, metaphorically, freedom and democracy in the lives of all people; love, freedom and democracy, like "light", ward off the darkness of racial hatred and prejudicial police brutality. Okri, ever timely to the times, wrote another poem (' $A$ Time Comes') on the unjust murder of George Floyd, and in this poem, he weaves language in a very symbolic manner, to interpret and criticise the racial temperature of our times. This is what he (Okri, 2021) says in that prose poem, symbolically:
A time comes when the cry for justice overwhelms the lands.
A people suffer brutalisation by the police, endure
all shades of discrimination, are the first to lose their jobs
and are the ones who die the most when the pandemic strikes.
And then one day, in Minneapolis, a police officer has a black man in a chokehold for more than eight minutes, and the man says 'I can't breathe' thirteen times before he dies and the world erupts.
Perhaps now in this pandemic we all know what it means when a human being says 'I can't breathe.

With this poem, published online by the Coronet Theatre (2021), Okri fittingly uses George Floyd, and his murder as symbols of our times, and he challenges all people to wake up from the racial hatred that has since created rifts, caused unjust arrests of black people, prejudicial police brutality, islamophobia and the fear of immigrants, of which Okri says "they still drown on the margins of Europe." (Okri, 2021:3). Barack Obama, and Nelson Mandela too, feature in Okri's poetry, particularly in the poem 'Obama', as symbolic personages through which Okri drives home his points, lessons and challenges to humanity.

George Floyd features in Okri's poetry as a symbol for all those people in the world who are marginalised, brutalised, discriminated against and ignored by others who consider themselves to be superior beings. Okri therefore is calling upon people to listen to the voices from the margins, to free those brutalised, to see that those regarded not so much as human beings, and subsequently discriminated, are in fact our own brothers and sisters. Symbols or 
a language of symbolism appeal to the reader more than every day speech. Hans Biedermann opines that "Symbols, they claim, enable people to bring the incomprehensible into the realm of the tangible, where they can deal with it." (Biedermann, 1989: vii).

The 'I can't breathe' phrase uttered by the late George Floyd as he was pressed down in a chokehold by a White police officer (See Transcript - The New York Times, 15 June 2021; Samayeen, Wong \& McCarthy, 2020), according to Okri (2021), has since been with us before Floyd's unjust murder, symbolic of the deprivation of "air" (the deprivation of human rights and dignity) that the racial bias and racism has trained upon black people and other races that have and still experience racism all across the world; and Okri seals off his insight on the condition of the world by saying Coronavirus should amplify and exemplify what it means to be denied rights. Okri uses the pinning down and ultimately snuffing out of the life of George Floyd as akin to all the suffering that human beings suffer under their governments, poverty, and the poor's inadequate access to health care.

There is a poem entitled 'Grenfell Tower', which is Okri's reaction to the fire that engulfed and killed more than 70 people including children (most of which were not native citizens of England) in the suburb of North Kensington, west London in England. The poem is symbolic of the suffering and the conditions in which immigrants live or are treated in foreign lands. As Okri writes in the poem, Grenfell Tower's fire and the death of the people, "Residents of the area call it the crematorium. It has revealed the undercurrents of our age." (Okri, 2021:131). Okri presents the poem as a symbolic revelation of what has been hidden, especially with the line: "Sometimes it takes an image to wake a nation/from its secret shame". Okri portrays the burnt Tower and the dead poor - "who thought voting for the rich would/save them" (Okri, 2021:131) - as symbols that revealed the "cladded" truths about the socio-economic and political temperature of the world. Okri uses the tower as a microcosm of all the hidden shames and truths in the world, and he hints at the idea that such secret things will be revealed, though often with unfortunate loss, and the sacrifice of innocent lives. The description of the burnt tower, which conjurers up horrific visual imagery, and the noting of people jumping from the tower to their death, creates kinaesthetic imagery which appeals to the reader's emotions of horror, anger and despondency. This is all due to Okri's unique, rich, interrogative, pungent and intrepid poetic discourse.

\section{Visions and submissions of a poet-seer}

Okri offers us visions through his poetry; he is a visionary. According to Faris (2015:128), "Many of Okri's texts embody what has been called a "shamanic realism" because they bridge the worlds of everyday life and that of the spirits, as does shamanic practice, and therefore could be said to transmit a shamanic aura or voice". In a poem entitled 'Revolution', he (Okri) achieves a delivery of a pungent submission of his vision about the condition of the world. $\mathrm{He}$ (Okri) writes:

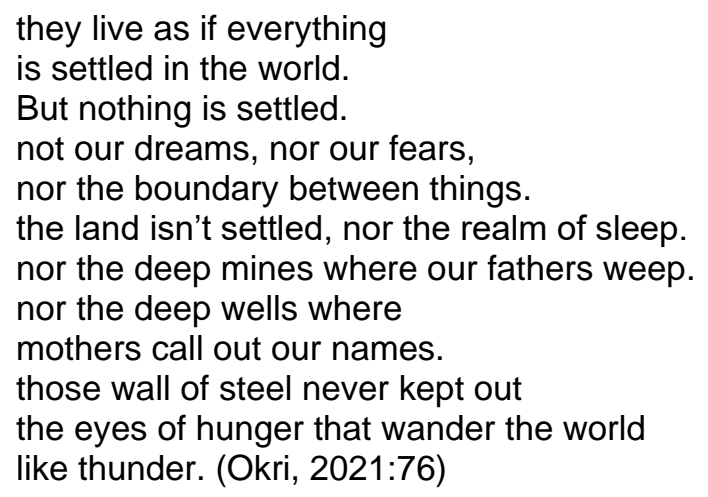

This is Okri's vision, that there is work to be done, the world is not settled, therefore human beings should not sleep, and the powers that may be, should not lead as if the future is here. This poem shares with the reader, a visionary and revolutionary thinking about the world, and 
in its listing of all the areas of our world, our lives that are not settled, the poet nudges the reader out of sleep. In a pandemic such as Covid-19, Okri's poetry has the power to make people partake in visions of a new future, even though the apparent state of affairs is that humankind is threatened with extinction. Okri offers a radical vision that refuses to see the pandemic as an end, but as an opportunity for people to now be cognisant of the fact that so many things in the world require work from all of us. Okri is a relevant poet-seer of contemporary times; he has a voice that weaves all the many problems of the world into a moving, awakening poetic tapestry.

\section{Conclusion}

Okri's poetry is rich with a plethora of issues, themes and ideas that when explored, and interpreted, could release poetic revelations, explosions of new ideas and new dreams, new ways of seeing, new ways of dreaming, which Okri regards as healing (Okri, 2013). Okri's writing, precisely his poetry, is preoccupied with reawakening the spiritual sensibility and social-consciousness of the people. People should then listen to poets, read poetry, especially in times of crisis, because poetry might just be one of the flames that humanity needs to start a new future. In his books of poetic essays and aphorisms, A Time for New Dreams, Okri reveals to the reader, that: "Poets want nothing from you, only that you listen to your deepest selves. Unlike politicians, they don't want your votes" (2019:7). It is therefore important that poets are listened to, for a nation that does not listen to its poets is on the brink of a terrible silence and death. So, here is a fitting coda to this paper from Okri: "Let us bring together the voices of poetry from all the world, and make our hearts a festival, a dreaming place, and our minds an academy of essentials under the stars" (Okri, 2019:4).

Note: This forms part of the research project: Investigating local indigenous community perspectives in response to the COVID-19 pandemic: An invisible enemy in the midst of our local households, supported by the National Institute for Humanities and Social Sciences (NIHSS), under Health and indigenous knowledge systems (IKS) Research Cluster.

\section{References}

Adrienne, R. (2007). Legislators of the world, Community Development Journal, 42(4), 422-424. Available online at https://doi.org/10.1093/cdj/bsm033 [Accessed 03 June 2021].

Aldrovandi, C. (2014). Apocalyptic movements in contemporary politics. New York: Palgrave Macmillan.

Allende, I. (1993). Writing as an act of hope. Peace Review, 5(2), 165-175.

Anandawansa, K. (2014). Literature as a function of Aristotelian Catharsis: A Study in relation to Shame by Salman Rushdie. In Proceedings of Jaffna International Research Conference (JUICE-2012) (141-147).

Ashcroft, B., Griffiths, G. and Tiffin, H. (2003). The empire writes back: Theory and practice in post-colonial literatures. London: Routledge.

Baldwin, J. (2016). Go Tell it on the Mountain. Everyman's Library.

Biedermann, H. (1989). The Wordsworth Dictionary of Symbolism. New York: Facts on File.

Birat, K. (2015). 'Through a bending light': Ben Okri's poetic commitment. Commonwealth Essays and Studies, 38(1), 1-45.

Brandom, R. (2004). Hermeneutic practice and theories of meaning. SATS-Nordic Journal of Philosophy, 5, 5-26. 
Chikogu, R.N. \& Ofuani, O.A. (2012). SEMANTIC FOREGROUNDING, POETICISATION AND DRAMATISATION IN BEN OKRI'S ABIKU TRILOGY. Nigerian Journal of the Humanities, 142, 141-176.

Cobb, M. (2001). The dying soul: Spiritual care at the end of life. United Kingdom: McGrawHill Education.

Crwys-Williams, J. (2012). The Penguin Dictionary of South Africa Quotations. South Africa: Penguin Random House South Africa.

Davies, S. (2018). Definitions of art. Cornell University Press.

Dein, S. (2021). Covid-19 and the apocalypse: religious and secular perspectives. Journal of religion and health, 60(1), 5-15.

Derderian, S.L. (2007). Alexander Fleming's miraculous discovery of Penicillin. Rivier Academic Journal, 3(2), 1-5.

Dirven, R. \& Bernard, M. (1991). Metaphoric Process/Metaphor and Religious Language (Book). Metaphor and Symbol, 6(1), 57-60.

Eagleton, T. (1983). Literary theory: An introduction. Minneapolis: University of Minneapolis Press.

Faris, W.B. (2015). Scenes of Enchantment: Visionary Style in Ben Okri's Dangerous Love. Research in African Literatures, 46(1), 127-141.

Gaynes, R. (2017). The discovery of penicillin-new insights after more than 75 years of clinical use. Emerging infectious diseases, 23(5), 849-853.

Gero, S. (1976). The Spirit as a Dove at the Baptism of Jesus. Novum Testamentum, 18(1), 17-35.

Gray, R.A. (2020). The Tough Alchemy of Ben Okri. Bloomsbury Publishing.

Gray, R.A. (2016). Promoting the poetic cause in Ben Okri's stokus from Tales of freedom (2009). Literator (Potchefstroom. Online), 37(1), 1-10.

Guignery, V. (2015). Ben Okri: A Man of Many Arts. Callaloo, 38(5), 997-1003.

Horea, I.C. \& Horea, C.D. (2014). Metaphorical Language and Polysemy of the Religious Texts. International Journal, 2(1), 45-58.

Joubert, J. (2007). Johannine metaphors/symbols linked to the Paraclete-Spirit and their theological implications. Acta theologica, 27(1), 83-104.

Kaufman, J.C. \& Baer, J. (2002). I bask in dreams of suicide: Mental illness, poetry, and women. Review of general psychology, 6(3), 271-286.

Knorr, E., 2015. Revelation and Bible Prophecy-A Comparison of Eschatological Views: Dispensationalism and Preterism. Online article available at http://www. cs. ubc. ca/ knorr/public/comparison_of_eschat_models, 15-12.

Landa, J.A.G. (2014). Notes on Richard E. Palmer's' Hermeneutics: Interpretation Theory in Schleiermacher, Dilthey, Heidegger and Gadamer'. Net Sight de José Angel García Landa.

Leedy, J.J. (1969). Poetry Therapy; The Use of Poetry in the Treatment of Emotional Disorders.

Lepherd, L. (2015). Spirituality: Everyone has it, but what is it?. International Journal of Nursing Practice, 21, 566-574. 
Mcardle, S. \& Byrt, R. (2001). Fiction, poetry and mental health: expressive and therapeutic uses of literature. Journal of Psychiatric and Mental Health Nursing, 8(6), 517-524.

Mich, S. (2017). Is there a relationship between Poetry and Spirituality? Is there a relationship between Poetry and Spirituality? / New Baltimore, MI Patch. (Accessed: 06 June 2021).

Milona, M. (2020). Philosophy of Hope. In Historical and Multidisciplinary Perspectives on Hope (99-116). Springer, Cham.

Muganga, L. (2015). The importance of hermeneutic theory in understanding and appreciating interpretive inquiry as a methodology. Journal of Social Research \& Policy, 6(1), 64-88.

Oates, J.C. (1978). "Margaret Atwood: Poems and Poet." The New York Times Book Review 21 May: 15, 43-45.

Nigg, J. (2016). The Phoenix: An Unnatural Biography of a Mythical Beast. United States of America: University of Chicago Press.

Noorderhaven, N. (2000). Hermeneutic methodology and international management research. Företagsekonomiska institutionen.

Obumselu, B. (2011). Ben Okri's" The Famished Road": A re-evaluation. Tydskrif vir letterkunde, 48(1), 26-38.

Okri, B. (2021). Mental fight: an epic poem. United Kingdom: Head of Zeus Ltd.

Okri, B. (2019). A Time for New Dreams. United Kingdom: Head of Zeus Ltd.

Okri, B. (2019). The Freedom Artist. United Kingdom: Head of Zeus Ltd.

Okri, B. (2015). An African Elegy. London: Random House.

Okri, B. (2015). 11.debat: Lezing Ben Okri - deel 1. [video] Available online at: https://www.youtube.com/watch?v=m2VEL2_u4s8 [Accessed 27 May 2021].

Okri, B. (2015). 11.debat: Lezing Ben Okri - deel 2. [video] Available online at: https://www.youtube.com/watch?v=jFjKztov_GQ [Accessed 28 May 2021].

Okri, B. (2014). A way of being free. United Kingdom: Head of Zeus.

Okri, B. (2012). Wild. United Kingdom: Random House.

Okri, B. (2012). Ben Okri Speaking at UCT: $13^{\text {th }}$ Annual Steve Biko Memorial Lecture. [video] Available online at: https://www.youtube.com/watch?v=uhre8OP7Rkw [Accessed 04 June 2021].

Okri, B. (2010). Ben Okri in Conversation with Vanity Fair's Anderson Tepper. [video] Available online at: https://www.youtube.com/watch?v=TErh21yWKtc [Accessed 12 June 2021].

Okri, B. (2009). Tales of freedom. United Kingdom: Random House.

Okri, B. (2007). Starbook. United Kingdom: Chatham.

Pagani, C. (2016). The Role of Art in Society with Particular Reference to the Problem of Violence. The Open Psychology Journal, 9, 160-167.

Raingruber, B. (2004). Using poetry to discover and share significant meanings in child and adolescent mental health nursing. Journal of Child and Adolescent Psychiatric Nursing, 17(1), 13-20. 
Rowling, J.K. (2008). J K Rowling Speaks at Harvard Commencement. Harvard Magazine, 5.

Rowell, C.H. (2014). An Interview with Ben Okri. Callaloo, 37(2), 214-221.

Saisuta, P.N. (2012). The Buddhist core values and perspectives for protection challenges: faith and protection. High Commissioner's Dialogue Distr: General on Protection Challenges Theme: Faith and Protection.

Samayeen, N., Wong, A. \& McCarthy, C. (2020). Space to breathe: George Floyd, BLM plaza and the monumentalization of divided American Urban landscapes.

Scioli, A. (2007). Hope and spirituality in the age of anxiety. In Advancing quality of life in a turbulent world (135-150). Springer, Dordrecht.

Shelley, P.B., Garland, P., Marquard, R. \& Watson, G. (1969). A defence of poetry (509-38). Haldeman-Julius.

Smith, N.H. (2010). From the concept of hope to the principle of hope. In Hope Against Hope (1-22). Brill Rodopi.

Spencer, M. (2012). What is spirituality? A personal exploration. Retrieved March, 16: 2020.

Tan, S.Y. \& Tatsumura, Y. (2015). Alexander Fleming (1881-1955): discoverer of penicillin. Singapore medical journal, 56(7), p.366-367.

Teimouri, M. (2011). Time and Vision in Ben Okri's The Famished Road. SARJANA, 26(2), $1-14$.

Tolstoy, L. (19950. What is art?. UK: Penguin.

Tunca, D. (2011). Okri, Ben (1959-). Dictionary of African Biography, Oding-Teres, 5, 23-25.

Tunca, D. (2004). Ben Okri's The Landscapes within and Dangerous love: Vision and revision. BELL. Belgian Journal of English Language and Literatures, 2, 85-101.

Ulafor, O.J. (2020). Martin Luther King Jr's philosophy of non-violence: A paradigm for global black race towards conflict resolution and peace in Africa. Jurnal Sosialisasi: Jurnal Hasil Pemikiran, Penelitian Dan Pengembangan Keilmuan Sosiologi Pendidikan, 54-61.

Zabán, B.K. (2016). Metaphors in the Wisdom Literature of the Hebrew Bible and Contemporary Art. Religions, 7(9), 1-14.

Warnes C. (2009). Magical Realism as Postcolonial Romance. In Magical Realism and the Postcolonial Novel. Palgrave Macmillan, London. Available online at https://doi.org/10.1057/9780230234437_2.

Watch, K., 2012. keeping watch.

Wilde, O. (2000). The picture of Dorian Gray. England: Penguin Group.

Williams, C.K. (1987). Poetry and consciousness. The American Poetry Review, 16(1), 27-30. 